Volume 10, No.3, May - June 2021

International Journal of Advanced Trends in Computer Science and Engineering

Available Online at http://www.warse.org/IJATCSE/static/pdf/file/ijatcse771032021.pdf

https://doi.org/10.30534/ijatcse/2021/781032021

\title{
IOT Framework for Heart Diseases Prediction Using Machine Learning
}

\author{
BALJINDER KAUR \\ GNDU, Amritsar Punjab, INDIA (CSE) \\ Kbaljinder201@gmail.com
}

\begin{abstract}
latest evolution in the domain of internet of things and technology of sensors can be carrier for online healthcare services. The modern rectification in IOT sector enhance the employed rate in online healthcare control. So according to in this paper we proposed a framework for heart diseases prediction with the help of IOT and machine learning. Basically IOT sensors attached with patient body and that sensors transfers the patient data into dataset form. Then help with the machine learning classification algorithms predict the data for patient having a normal or abnormal form of data.
\end{abstract}

Key words: IOT, Machine learning algorithms, UCI Repository dataset

\section{INTRODUCTION}

IOT is technology in which anybody else exchange the data from one device to another one with the help of distinct software. In other words, people can transfer the data about anything else such as about the prediction of any disease for instance, estimate of cancer by its symptoms. One can also use the IOT technology in share markets for predicting the fluctuation about share prices and so on. In this given research paper I explore the way of using IOT framework for predicting the heart disease with help of machine learning classifiers algorithms using WEKA tools as well such as UCI repository heart diseases dataset. This paper includes the smart healthcare using IOT, sensor to machine, machine to sensor, patients to IOT devices, and patient to physician, and devices to physician communications. The IOT have various application together with remote monitoring, early preventions, cardiovascular diseases management, voice pathology, and health related treatment for isolated the patient etc. that is allowed us to establish intuitive interrelations insure a essential healthcare system. Healthcare is the major socio- economically bother providing health center and providing healthcare worker to us might be the complications to some passably. In this research the Smart medical prosecution the important privacy have to do with convince outstretched and provocation designation require, authorize consistent associate connecting the tolerant, medical sensors and medical portioned. The sensors will data in a continually deportment, Then corresponding amidst indispensable anatomically specification transmission through the noncable network. Then predicted information is set aside, transformed and analyzed with previous information. Used the previous information and decisions' base frame, medical practitioner make more acceptance predicting then suggesting to take treatment on early states of disease. Unfortunately doctors not present, that prediction validate nowadays machines they are available medication standardized analysis of the medical datasets. Over the past four decade our epoch tin be narrate as big data epoch emplacement digital is flattering progressively supreme numerous fields like. Medical management, science technology and civilization. Multiple types of data had been apprehending or produce belonging multiplex zones, several sources for instances simultaneously cascade Machines, larger yielding mechanism, sensors and crisscross, cell phone applications and belonging each one streams unusually medical management, there are more information dimensions define Big data. Hoard, distilling, anticipate and intellect genealogy among dimensions or diverse data types enhance a challenges. Internet of things enlarge carry on with observe orderly execute instantaneous movements case of needs exceptionally as long as diseases. Consequent, the thousands devices perform enormous quality of information. Distilling that information accomplishment instantaneous measures captious circumstances imperilment. Formulated on the challenging appearance between medical management. Information belong inning devices go through procedure design identification and machine learning techniques. For the purpose manipulate additionally heterogeneous and consistently exchange device information, machine learning should be progress more. Correspondingly Algorithm's importantly proficient marketing automatically misplaced values, flow information diverse measurements connotation since pattern of devices repeatedly changes. Now days will be normally set down proximity with the decorticate in multiple biological structure large rely higher level attain precise compute. Belonging dense device submerged as well as patient's biological structure, physiologically information gathering. Unfluctuating many mandatory necessary physiologically parameter. Further a microscopic instruments 
able for vulcanization and obtain information and a communicating software to disseminate information. The sensors compulsory be a microscopic, insubstantial or does not distress the patient potency or gesticulation. That sensors should execute on short range, power well-arranged accumulator are anticipate did jobs continuously free of charges replacement. The structure component blameworthy for information transmitting compulsory cable to exchange storing the patients belonging to them locations to medical management center with precision and Privacy.

\section{LITERATURE REVIEW}

Table 1: literature review for existing researches

\begin{tabular}{|c|c|c|c|}
\hline REFERENCE & TECHNIQUE & MERITS & Demerits \\
\hline $\begin{array}{l}\text { 1).MD Milon } \\
\text { Islam } \\
\text { Ashikur } \\
\text { Rahman\& } \\
\text { MD.Rashdul } \\
\text { Islam } \\
\text { (26 MAY } \\
\text { 2020) }\end{array}$ & $\begin{array}{l}\text { Development of } \\
\text { smart healthcare } \\
\text { monitoring } \\
\text { system in IOT } \\
\text { environment. }\end{array}$ & $\begin{array}{l}\text { The most } \\
\text { significant } \\
\text { pro of IOT } \\
\text { according } \\
\text { to given } \\
\text { paper is } \\
\text { that, it } \\
\text { gives } \\
\text { appropriate } \\
\text { data about } \\
\text { tremendou } \\
\text { s patients at } \\
\text { single time. }\end{array}$ & $\begin{array}{l}\text { On the } \\
\text { flip side } \\
\text { This paper } \\
\text { also } \\
\text { reveals } \\
\text { that this } \\
\text { technology } \\
\text { also has } \\
\text { some } \\
\text { drawbacks } \\
\text { and using } \\
\text { hefty } \\
\text { machines } \\
\text { in this } \\
\text { technology } \\
\text { is one of } \\
\text { them. }\end{array}$ \\
\hline $\begin{array}{l}\text { 2) .Ibrahim } \\
\text { Sadek, } \\
\text { Shafiq } \\
\text { Ul } \\
\text { Rehma } \\
\text { n, } \\
\text { Josue } \\
\text { Codjo, } \\
\text { Bessa } \\
\text { m } \\
\text { Abdulr } \\
\text { azak. } \\
\text { OCTOBER } \\
\text { 2019) }\end{array}$ & $\begin{array}{l}\text { icy and security of } \\
\text { IOT based } \\
\text { healthcare system } \\
\text { concerns } \\
\text { solutions and } \\
\text { recommendations }\end{array}$ & $\begin{array}{l}\text { s paper is } \\
\text { attentively } \\
\text { connected } \\
\text { to human } \\
\text { beings } \\
\text { there for } \\
\text { security is } \\
\text { major } \\
\text { concerns. } \\
\text { Mainly this } \\
\text { paper } \\
\text { works on } \\
\text { internet of } \\
\text { things } \\
\text { sleep } \\
\text { trackers } \\
\text { and find as } \\
\text { a required } \\
\text { ensure } \\
\text { rectified. }\end{array}$ & $\begin{array}{l}\text { There are } \\
\text { ample of } \\
\text { demerits } \\
\text { behind this } \\
\text { trend but } \\
\text { the main } \\
\text { underlying } \\
\text { is leakage } \\
\text { of } \\
\text { important } \\
\text { data. }\end{array}$ \\
\hline $\begin{array}{l}\text { 3) .Mohamad } \\
\text { Ayoub } \\
\text { Khan } \\
(17\end{array}$ & $\begin{array}{l}T \text { framework for } \\
\text { heart disease } \\
\text { prediction based } \\
\text { on MDCNN }\end{array}$ & $\begin{array}{l}\text { et of things } \\
\text { model } \\
\text { present } \\
\text { appraise }\end{array}$ & $\begin{array}{l}\text { To } \\
\text { improve } \\
\text { more } \\
\text { accuracy }\end{array}$ \\
\hline
\end{tabular}

\begin{tabular}{|c|c|c|c|}
\hline $\begin{array}{l}\text { FEB } \\
2020)\end{array}$ & classifier. & $\begin{array}{l}\text { Heart } \\
\text { diseases } \\
\text { additional } \\
\text { accuracy } \\
\text { used by a } \\
\text { modified } \\
\text { deep } \\
\text { convention } \\
\text { al neural } \\
\text { network. }\end{array}$ & $\begin{array}{l}\text { using } \\
\text { different } \\
\text { features } \\
\text { selections } \\
\text { algorithm } \\
\text { and } \\
\text { optimizati } \\
\text { on } \\
\text { techniques } \\
\text {. }\end{array}$ \\
\hline $\begin{array}{l}\text { Albhri, A.S A.A } \\
\text { Zaidan }\end{array}$ & $\begin{array}{l}\text { tolerant m-health } \\
\text { framework in the } \\
\text { context of IOT } \\
\text { based real-time } \\
\text { wearable health } \\
\text { data sensors. }\end{array}$ & $\begin{array}{l}\text { ed } \\
\text { experience } \\
\text { d physician } \\
\text { to a } \\
\text { patient's in } \\
\text { an isolated } \\
\text { environme } \\
\text { nt or } \\
\text { accommod } \\
\text { ate a } \\
\text { predomina } \\
\text { nt supervision } \\
\text { medical PR } \\
\text { actioner } \\
\text { too. }\end{array}$ & $\begin{array}{l}\text { Too } \\
\text { mainly it's } \\
\text { working } \\
\text { only a } \\
\text { risky } \\
\text { patient. } \\
\text { Only } \\
\text { providing } \\
\text { a list of } \\
\text { selected } \\
\text { hospitals. }\end{array}$ \\
\hline \begin{tabular}{|r} 
5) Fahad \\
Taha \\
Ai- \\
Dhief, \\
Nurul \\
MU \\
Azzah
\end{tabular} & $\begin{array}{l}\text { Survey of voice } \\
\text { Pathology } \\
\text { Surveillance } \\
\text { system based an } \\
\text { internet of things } \\
\text { and machine } \\
\text { learning. }\end{array}$ & $\begin{array}{l}\text { searcher } \\
\text { proposed a } \\
\text { immense } \\
\text { analysis of } \\
\text { the modern } \\
\text { technologie } \\
\text { s and ML } \\
\text { ALGORIT } \\
\text { HMS } \\
\text { utilized in } \\
\text { the medical } \\
\text { manageme } \\
\text { nt in } \\
\text { mainstrea } \\
\text { ms in the } \\
\text { voice } \\
\text { pathology } \\
\text { observation } \\
\text { system. }\end{array}$ & $\begin{array}{l}\text { Pathology } \\
\text { has not } \\
\text { gained } \\
\text { much } \\
\text { attention, } \\
\text { where } \\
\text { there is an } \\
\text { urgent } \\
\text { need in } \\
\text { this area } \\
\text { due to the } \\
\text { shortage of } \\
\text { research } \\
\text { and } \\
\text { diagnosis } \\
\text { of lethal } \\
\text { diseases. }\end{array}$ \\
\hline $\begin{array}{l}\text { 6) Sanjay } \\
\text { Sareen } \\
\text { Sandee } \\
\text { p K. K. } \\
\text { Sood } \\
\text { and } \\
\text { Sunil } \\
\text { Kumar } \\
\text { Gupta. }\end{array}$ & $\begin{array}{l}\text { based cloud } \\
\text { framework to } \\
\text { control EBOLA } \\
\text { virus outbreak. }\end{array}$ & $\begin{array}{l}\text { Research is to } \\
\text { preventing } \\
\text { the extend } \\
\text { of the virus } \\
\text { at the } \\
\text { starting } \\
\text { point of the } \\
\text { epidemic. }\end{array}$ & $\begin{array}{l}\text { This } \\
\text { machine } \\
\text { only work } \\
\text { in the } \\
\text { beginning } \\
\text { stage of } \\
\text { the given } \\
\text { virus. }\end{array}$ \\
\hline $\begin{array}{l}\text { 7) Rohit } \\
\text { Rastog }\end{array}$ & $\begin{array}{l}\text { gent heart disease } \\
\text { prediction }\end{array}$ & $\begin{array}{cr}\text { OT } & \text { system } \\
\text { give } & \text { actual }\end{array}$ & $\begin{array}{l}\text { User needs } \\
\text { to }\end{array}$ \\
\hline
\end{tabular}




\begin{tabular}{|c|c|c|c|c|c|c|c|}
\hline \multirow{2}{*}{\begin{tabular}{|l} 
i DK \\
Chatur \\
vedi \\
Santos \\
h Satya \\
Navne \\
et \\
Arora \\
0 MARCH 2020)
\end{tabular}} & \multirow{2}{*}{$\begin{array}{lr}\text { Physical and } \\
\text { Mental } \\
\text { parameters; } \\
\text { ML based } & \text { IOT } \\
\text { and big data } \\
\text { applications } & \text { and } \\
\text { analysis. } & \end{array}$} & \multirow{2}{*}{$\begin{array}{l}\text { data about } \\
\text { the health } \\
\text { of patient } \\
\text { which } \\
\text { ethnic } \\
\text { machines } \\
\text { does not } \\
\text { provides }\end{array}$} & \multirow{2}{*}{$\begin{array}{l}\text { specially } \\
\text { register in } \\
\text { the system. } \\
\text { And } \\
\text { received } \\
\text { user only } \\
\text { two types } \\
\text { of outputs } \\
\text { only } \\
\text { binary } \\
\text { language. }\end{array}$} & & & & $\begin{array}{l}\text { assisting } \\
\text { the special } \\
\text { environme } \\
\text { nt. }\end{array}$ \\
\hline & & & & \multirow[t]{2}{*}{\begin{tabular}{|r|} 
9) OANA \\
GEMA \\
N, LE \\
HOAN \\
G SON \\
66 JULY 2019)
\end{tabular}} & \multirow[t]{2}{*}{$\begin{array}{l}\text { pased heart activity } \\
\text { monitoring using } \\
\text { inductive sensors }\end{array}$} & \multirow{2}{*}{$\begin{array}{l}\text { st quality of } \\
\text { this } \\
\text { technology } \\
\text { is } \\
\text { monitoring } \\
\text { it detect the } \\
\text { condition } \\
\text { of patients } \\
\text { continuous } \\
\text { ly and } \\
\text { gives the } \\
\text { accurate } \\
\text { data. }\end{array}$} & \multirow{2}{*}{$\begin{array}{l}\text { Need to be } \\
\text { a future } \\
\text { work to } \\
\text { correlate } \\
\text { analytical } \\
\text { devices } \\
\text { informatio } \\
\mathrm{n} \quad \text { with } \\
\text { ECG } \\
\text { signals } \\
\text { advance } \\
\text { informatio } \\
\mathrm{n} \\
\text { sequence } \\
\text { to } \\
\text { apparatus } \\
\text { another } \\
\text { framework } \\
\text { for } \\
\text { intuitive } \\
\text { materials. }\end{array}$} \\
\hline \multirow[t]{3}{*}{\begin{tabular}{|cc} 
8) & V.Jagdesh \\
& wara \\
RI, & V.Subr \\
amany & Aswa \\
my, \\
Viayku \\
mar \\
September 2020)
\end{tabular}} & \multirow[t]{3}{*}{$\begin{array}{l}\text { dy on Medical } \\
\text { Internet of Big } \\
\text { data } \\
\text { Personalized } \\
\text { healthcare system }\end{array}$} & \multirow[t]{3}{*}{$\begin{array}{l}\text { main } \\
\text { underlying } \\
\text { of this } \\
\text { technique } \\
\text { is gives } \\
\text { appropriate } \\
\text { advice } \\
\text { about } \\
\text { healthcare } \\
\text { centers and } \\
\text { also gives } \\
\text { guidelines } \\
\text { about } \\
\text { preventing } \\
\text { the patients } \\
\text { for more } \\
\text { diseases. }\end{array}$} & \multirow{3}{*}{$\begin{array}{l}\text { Througho } \\
\text { ut } \\
\text { cell-phone } \\
\text { base } \\
\text { medical } \\
\text { manageme } \\
\text { nt } \\
\text { requisition } \\
\text { come up } \\
\text { with } \\
\text { substantial } \\
\text { occasion } \\
\text { upgrade } \\
\text { senior } \\
\text { subject } \\
\text { could not } \\
\text { depended } \\
\text { on } \\
\text { cell-phone } \\
\text { s every } \\
\text { time those } \\
\text { people } \\
\text { does not } \\
\text { awareness } \\
\text { about } \\
\text { technology } \\
\text { and does } \\
\text { not able to } \\
\text { use easily. }\end{array}$} & & & & \\
\hline & & & & $\begin{array}{l}\text { 10) M.Ganesa } \\
\text { n } \quad(30 \\
\text { March } \\
\text { 2019) }\end{array}$ & $\begin{array}{l}\text { ased heart disease } \\
\text { prediction and } \\
\text { diagnosis model } \\
\text { for healthcare } \\
\text { using machine } \\
\text { learning models. }\end{array}$ & $\begin{array}{l}\text { advancement } \\
\text { of this } \\
\text { paper gives } \\
\text { effective } \\
\text { way of } \\
\text { prediction } \\
\text { about } \\
\text { disease. }\end{array}$ & $\begin{array}{l}\text { Not easily } \\
\text { understoo } \\
\text { d by } \\
\text { patient. }\end{array}$ \\
\hline & & & & \multirow[t]{3}{*}{$\begin{array}{l}\text { 11) S. } \\
\text { Mahal } \\
\text { akshmi } \\
\text {, Dr.R. } \\
\text { Latha }\end{array}$} & \multirow[t]{2}{*}{$\begin{array}{l}\text { ntelligence with } \\
\text { Internet of things } \\
\text { on healthcare } \\
\text { systems: Survey. }\end{array}$} & \multirow{2}{*}{$\begin{array}{l}\text { is research } \\
\text { author } \\
\text { introduce } \\
\text { the model } \\
\text { for } \\
\text { healthcare } \\
\text { systems } \\
\text { provides } \\
\text { knowledge } \\
\text { for various } \\
\text { challenges, } \\
\text { security } \\
\text { and issues } \\
\text { facing in } \\
\text { the existing } \\
\text { techniques } \\
\text { and also In } \\
\text { the } \\
\text { proposed } \\
\text { model. }\end{array}$} & \multirow{2}{*}{$\begin{array}{l}\text { Not easily } \\
\text { understoo } \\
\mathrm{d} \text { able the } \\
\text { common } \\
\text { man using } \\
\text { this } \\
\text { technique } \\
\text { simply } \\
\text { users } \\
\text { needs a } \\
\text { intelligent } \\
\text { knowledge } \\
\text { in the } \\
\text { healthcare } \\
\text { systems. }\end{array}$} \\
\hline $\begin{array}{l}\text { MATASHEKHA } \\
\text { R SARMAH } \\
\text { JULY 2020) }\end{array}$ & $\begin{array}{l}\text { ost significant pro } \\
\text { of this } \\
\text { advancement is } \\
\text { giving actual and } \\
\text { accurate data } \\
\text { about the disease } \\
\text { of patient. }\end{array}$ & $\begin{array}{l}\text { most } \\
\text { significant } \\
\text { pro of this } \\
\text { advanceme } \\
\text { nt is giving } \\
\text { actual and } \\
\text { accurate } \\
\text { data about } \\
\text { the disease } \\
\text { of patient. }\end{array}$ & $\begin{array}{l}\text { It is higher } \\
\text { cost } \\
\text { framework } \\
\text { because } \\
\text { there are } \\
\text { using } \\
\text { various } \\
\text { technologi } \\
\text { es, no old } \\
\text { ager } \\
\text { persons } \\
\text { can } \\
\text { understan }\end{array}$ & & & & \\
\hline & & & $\begin{array}{l}\text { ds. Those } \\
\text { people's } \\
\text { needs to }\end{array}$ & & & & \\
\hline
\end{tabular}




\section{OBJECTIVES}

1) To promotes awareness of health care among all sections of the people.

2) Integration of temperature, pulse sensor, \& on single system.

3) Detect and inform the emergencies case as per patient health conditions.

4) Reduced documentation and paperwork

\subsection{Future Direction}

Modern industry employs technologies for automation that may include internet of thing (IOT), cloud and/ fog computing, as well as Artificial intelligence, (AI), machine learning $(\mathrm{Ml})$, or block chain.

\subsection{IOT Sensors Used in Paper \\ * HEART BEAT SENSOR \\ * eCG SENSOR \\ * BLOOD PRESURE SENSOR}

\section{HEART DISEASE PREDICTIONS RESULTS AND ANALYSIS}

Todays, times of era here are so many research papers are existing. That uses the data mining different algorithm on the datasets.so here are needs to predicts the different sets of rules performs especially good kind of datasets.

- Dataset collection

The database has taken from the UCI Repository. In the dataset having 13 attributes. The cardiovascular sickness remembered for this study 270 instances with no missing values. The dataset is conventionally used for diverse sort of heart illness. This study predicts the earlier stage of heart disease. For example: - heart failure, heart attack, chest pain etc. the attribute in this numeric data value. Those represents patient age from 30 to 66 years. There are $\mathrm{Cp}$ is represents pain type represent from the Rangel 11 to 4 . The testbpd is a recline blood pressure that wallow in scattered in the range of 92 to 100 . The fbs higher blood sugar range that is if 0 and 1 in Boolean values.

i.e true or false.the restecg is the laying down electro cardiovascular graphic

Consequence express as a three instances 0 to 2 . The thalach is the paramount heart rate bring about range belong 82 to 185 .the exang is the occupation of induce angina that is Boolean value. The illness is the goal class of the dataset designate heart disease with the names yes or no attribute's statistics. *characteristics AGE $\{<30,30-65,>=66\}$

*characteristics gender \{woman, man\}

* characteristics congestive heart failure \{mode angina, rare cardiac non-cardiac strain symptomless \}

*characteristics normal Blood Pressure \{in millimeters /mercury\}

*characteristics cholesterol in milligram/deciliter

*characteristics normal Blood Sugar $\{2=$ right; $6=$ wrong $\}$

*characteristics restecg electro cardiovascular graphic $\{$ ordinarily, unordinary\} $*$ characteristics thalach paramount heart rate achieved

*characteristics exertion effect angina $\{1=$ yess; $0=$ not $\}$

*characteristics ST desperation make beside put together relative undergo response

*characteristics highest peak exertion \{increase, decrease\}

*characteristics numeral of paramount repository

*characteristics thal: $\{3=$ ordinarily; $6=$ rebuild; $7=$ irreversible $\mathrm{m}$

Prediction of cardiovascular sickness \{fluoroscopy illness level\}

* Investigation the WEKA tools using its classifiers algorithms. Further, statically estimated are enter in data mining operating system for pre-processing eventually examine. Is this prong us collect put forward classifiers conclusion for each.

* Relative examined classifiers reached from implantations element, correspondence presentation o the classifier.

\section{MACHINE LEARNING TECHNIQUES}

5:1 J48: -The classification algorithms mainly connected when the measurements of inputs are high. J48 used recognize the tendency of patients with heart disease. It Reveals probability of every inputs attributes for the predictable states. A decision tree is a formation that comprise a base node, its bough and leaf nodes. Every inner node indicates examine on characteristics', each bough indicates conclusion of analysis, and every node holds a class label. The uppermost node in the tree is the branch node. J48 algorithm be associated with superlative machine learning algorithms to investigates dataset definitely or pursue. When this used for samples objective, it immerses more memory volume consume the accomplishment and accuracy in M-healthcare data.

$$
i(N)=\sum_{n=1}^{n} p\left(w_{i}\right) \log _{z} p\left(w_{i}\right)
$$

5:2 Naïve: - it is suppose that the experience of a definite characteristics is the liberated of the experience of other definite. Like as apple define as its sweets taste. In other words each feature liberated and define by its characteristics. 5:3 Bayes: - it depend upon the principle of Bayes theorem that is form Bayes theorem and utilizing for resolve classifying difficulties. It is a selective classifiers, that is analysis on the base of the probably on an object. 
$P(A \mid B)=\frac{P(B \mid A) \cdot \mathrm{P}(A)}{P(B)}$

5:4 ZERO R: - zero $R$ is the uncomplicated classification method that is depend upon the target and ignore predictors. Zero R mainly focused on the majority of class.

5:5 K-STAR: - K-STAR is a heuristic search algorithm for finding the $\mathrm{k}$ smallest path. The K-MEANS algorithm is a developmental algorithm that take up by name from its method of potency. The algorithm Clusters data into $\mathrm{k}$ gatherings where $\mathrm{k}$ is considered as an input parameter. The Clusters mean the group of items having same quality. In K-MEANS Clustering origination centralized collection made of use exceptions method is apply to locate the conclusions.

5:6 DECISSION TREE: - A Decision tree is a decision ease implementation technique used for a tree-like graph or framework of alternative or individual results as well as prospects occurrence results and effectiveness. That's based on detain to express a algorithm. Decision trees is normally employ beside performance exploration, express in decision prediction assist or perceive a method forthcoming unquestionably appear towards impartial. A Decision tree excluding considerable expend replace quantities administration portrayed from branching node to the leaflet separately. Eventually by adhering to this ordinary, satisfactory conclusions can be obtainable.

5:7 Simple logistic: -Simple logistic is an analysis algorithm make use of variable demand to analysis categorical, meaning that undergo group, rather it is measureable and categorical. That is estimated such as possibility so that eventually might happened informally choice monitoring as compared to the possibility eventually did not occurred.

5:8 RANDOM FOREST: - Random Forest is a separate belong to decision tree algorithms extraction. This improves the previous task of decision trees establishment the distinguish tree. Random Forest breaks branching make use of finest amidst subdivision of predictor that choose at randomly. The algorithm face according to underneath. Initially, bring out the N-Tree reset test. Intending, for every sample, enlarge an unpruned clustering trees: at each branching, random test $\mathrm{n}$ make every effort prediction and choose finest break belong that elements. At that point, the analysis be directed forum assumption of $\mathrm{m}$ tree with higher majority. Individual, Random Forest have a hardly extremity compelling such as make use of in multi-class problems, larger analysis experiment.

5:9 Bayes Net: Bayesian grid or crucial Bayes Net algorithm is especially beyond-belief for sickness analysis structure given that made conclusion in situation of misplaced incoming information. That classifier makes use of a directed graph framework inform corporation in between various characters. Make use of such as reasonability predict appearance and skiving of separate sickness.

Accuracy: - It defines as below:
Accuracy $=\frac{T P+T N}{T P+T N+F P+F N}$

PRECISION- It defines as below:

precision $=\frac{T P+T N}{T P+F P}$

F- Measure- It defines as below:

$\mathrm{F}-$ measure $=\frac{2 T P}{2 T P+F P+T N}$

KAPPA Statics- It defines as below:

$$
=\frac{\mathrm{K}}{\text { OVEAALL ACCUAACY -EXPECTED-AGAEEMENT }}
$$

Recall- It defines as below:

precision $=\frac{T P+T N}{T P+F P}$

\section{PROPOSED MODEL}

The proposed structure model illustrates into flow chart. This is describes in mainly five parts i.e. medical sensors, disease prediction, heart disease data, stoical dataset and machine learning base heart disease prediction. With wearable sensors.

Playing the role of transferring patient data from the doctors. Then machine learning classifying algorithms applied on data sets and makes the result.

Figure: 1 flow chart of proposed framework

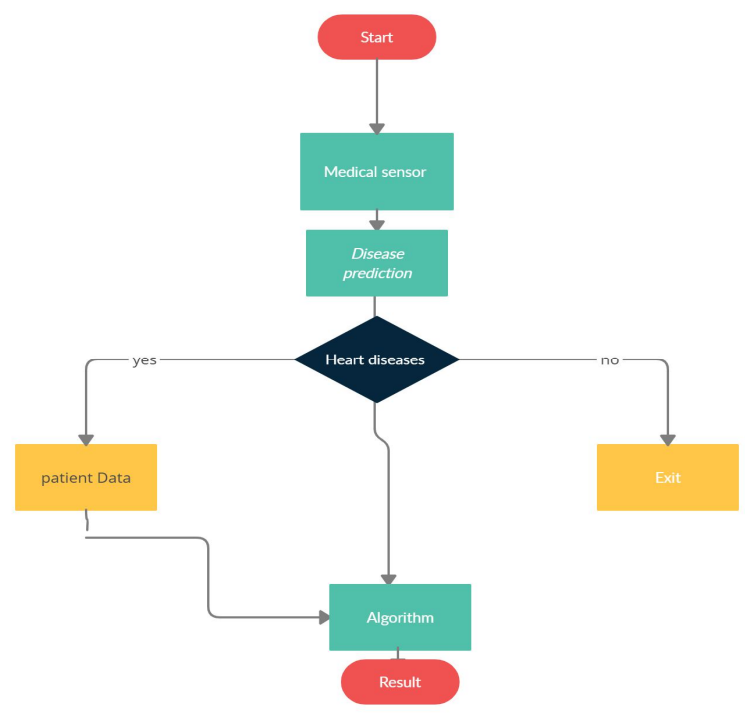

6.1 Results and Accuracy

Table: 2 Results

\begin{tabular}{|l|l|l|}
\hline Serial no. & Algorithms & Accuracy \\
\hline 1 & J48 & $92.56 \%$ \\
\hline 2 & Naïve Bayes & $85.71 \%$ \\
\hline 3 & Zero R & $52.49 \%$ \\
\hline 4 & K-Star & $60.70 \%$ \\
\hline 5 & Decision tree & $70.60 \%$ \\
\hline 6 & Simple logistic & $80.58 \%$ \\
\hline 7 & Random forest & $68.62 \%$ \\
\hline 8 & Bayes net & $82.49 \%$ \\
\hline
\end{tabular}


Figure: 2 Accuracy F Measure

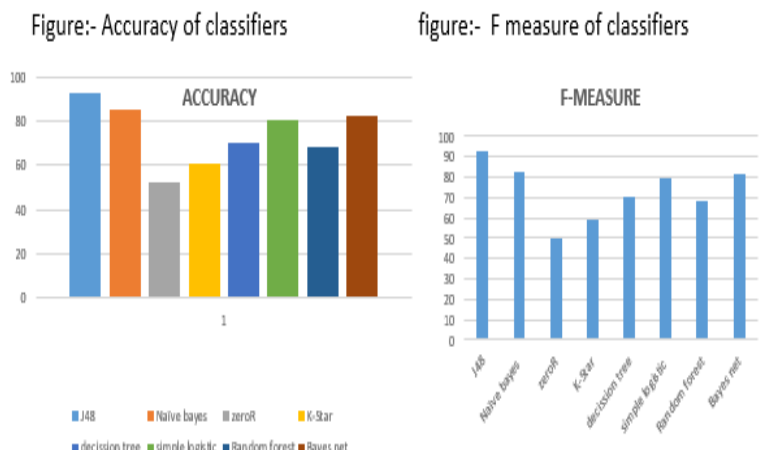

Figure: 3 Precision and Recall

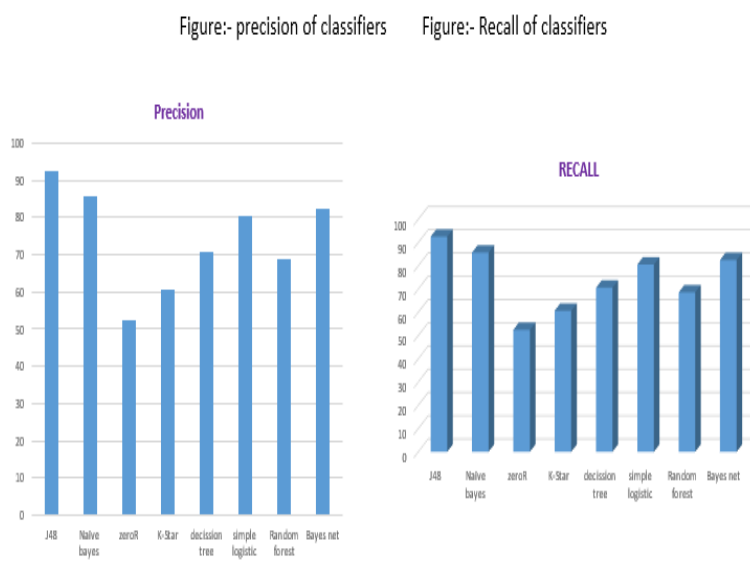

Figure:4 Roc area and kappa stastics

Figure:- Roc Area of classifiers figure:- kappa stastics

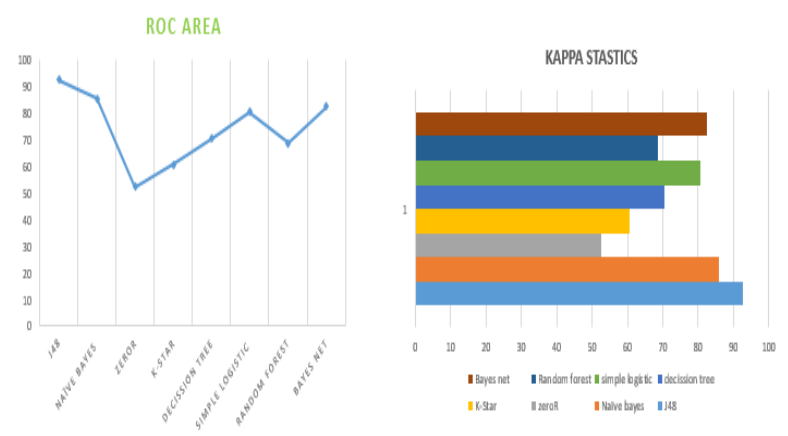

7.CONCLUSION

Heart diseases like cardinal diagnosis are most hazardous controversial matters over the globe. The assumption gives perception of numerous machine learning process which may be made in use of programming tic cardiovascular sickness analysis model. Cardiovascular sickness is main underlying cause behind deaths over the world moreover; early prediction of cardiovascular sickness is remarkable. The framework gives fruitful outcomes and is also helpful for monitoring the condition of the patient of heart disease and also gives the accurate data of disease through the given process such as ; recall, precision and ROC Area. The more accurate outcomes are founded in this research under the classify method at J48 classifier with 92.56 per centum accuracy. It is a most is most incredible outcome of any process

\section{REFERENCES}

1. Md. Milon Islam; Ashikur Rahaman \$ Md.Rashedul Islam; development of smart healthcare monitoring system in IOT environment. journel of springer; Citation [20] Paper publish in 26 may 2020.

2. Ibrahim Sadek, Shafiq UL Rehman; Josue codjo, Bessam Abdulrazak privacy and security of IOT based healthcare system concers: solutions and recommendation's journal of springer computer science; Citation [3]; paper publish 07 October 2019.

3. Mohammad Ayoub khan; IOT framework for heart disease prediction based on MDCNN classifiers. [6] Citations; journal of IEEE; paper publish 18 may 2020.

4. O.S Albahri; AS Albahri; AA Zaidan; BB Zaidan; MA Moshin; KL Mohammed; AH Alamoodi; IOT framework in the context of IOT based real-time wearable health data sensors. Citation [4]; paper publish11 April 2019.

5. Fahad Taha Al- Dhief ;Nurul MU azzah Abdul latiff; NIK Noordni Nik Abd.Malik; Naseer sabri salim; Marina Mat Baki; musa; surevy of voice pathology surveillance system based an internet of things and machine learnings citation [1]; paper publish 1 April 2020

6. Sanjay sareen; Sandeep K. Sood\& sunil kumar gupta; IOT based cloud framework to control EBOLA virus outbreak. Citations [26]; paper Publish 20 October 2016.

7. Rohit Rastog; DK Chaturved; Santosh Satya; Navneet Arora; intelligent heart disease prediction on physical and mental parameters, A ML based IOT and applications and analysis paper publish 10 march 2020.

8. .U.jagdeshwari; U. Subramaniyaswamy; R.Logesh \& Vijayakumar; A survey on medical internet of big data in personalized healthcare systems. Citation [53]; pp 20 September 2018.

9. Simanta Shekhar Samah; An efficient IOT based patient monitoring and heart disease prediction system using deep learning modified neural networks. Citation [1]; paper publish 6 July 2020.

10. Adrian Brezulianu; Oana Geman; Marius Dan Zbancioc; Marius Hagan; Cristain Aghion; D Jude Memath Le Hoaung Son; IOT based heart activity monitoring using inductive sensors. Paper publish 26 july2019.

11. . M Ganesan ; IOT based heart disease prediction and diagnosis model for healthcare using machine learning paper publish 30 March 2019. Journal of IEEE.

12. S. Mahalakshmi, Dr. R. Latha Artifficial Intelligence with the Internet of Things on Healthcare systems: A survey. 6 November /December 2919 Access 2019/27862019. 